\title{
Enjoyment as a learning resource: Stories told by students with harmful concentration problems
}

\author{
Audhild Løhre, Vigdis Vedul-Kjelsås and Ove Østerlie \\ Norwegian University of Science and Technology, NTNU, Norway
}

\begin{abstract}
Having concentration problems is typical within several diagnoses, such as ADHD, dyscalculia and dyslexia. This study aimed to explore how students experience their concentration problems in relation to schoolwork and what strategies could facilitate learning. Theory of play and motivation was applied. Twelve participants were selected by the local school to a program for concentration training, and individual interviews were conducted before the program started. Thematic analyses led to three main themes: sadness when learning is hampered, enjoyment in subjects and physical and mental sheltering. Perceptions of being academically left behind conveyed sadness in some students. However, substantial diversity characterised the students' like or dislike of subjects, and enjoyment seemed to vary with concentration. Institutional strategies with adapted teaching in separate rooms supported learning, and personal strategies to create pauses provided sheltering to regain concentration. To conclude, the various subjects were associated with significant diversity in enjoyment and concentration, pointing to a need for individual adaptation. Further, elements of play may increase motivation and concentration, and a context providing sheltering possibilities seems preferable.
\end{abstract}

Keywords: ADHD; dyscalculia; dyslexia; play theory; situated expectancy-value theory

Recieved: October, 2020; Accepted: March, 2021; Published: May, 2021

\section{Introduction}

This is the second study from a school-based intervention program in Mid-Norway involving target shooting practice. The object group consisted of 12 students with concentration problems that hampered their learning, of which half were diagnosed with attention deficit hyperactivity disorder (ADHD). The first publication (Løhre, 2020) investigated how the students described themselves in terms of inattentiveness, hyperactivity or impulsiveness and how those perceptions and their behaviour affected their identity, friendship and well-being. Although consciousness about

\footnotetext{
*Correspondence: Vigdis Vedul-Kjelsås, e-mail: vigdis.vedul-kjelsas@ntnu.no
}

(C) 2021 Audhild Løhre,Vigdis Vedul-Kjelsås \& Ove Østerlie. This is an Open Access article distributed under the terms of the Creative Commons Attribution 4.0 International License (https://creativecommons.org/licenses/by-nc/4.0/), allowing third parties to copy and redistribute the material in any medium or format and to remix, transform, and build upon the material for any purpose, even commercially, provided the original work is properly cited and states its license.

Citation: Audhild Løhre,Vigdis Vedul-Kjelsås \& Ove Østerlie. Enjoyment as a learning resource: Stories told by students with harmful concentration problems. Nordisk tidsskrift for pedagogikk og kritikk, Vol. 7, 2021, pp. 81-98. 


\section{A. Løhre, V. Vedul-Kjelsås \& O. Østerlie}

attentiveness differed among the students, all of them at some point in the interview described episodes that illustrated harmful concentration problems. There was no indication that concentration problems affected friendship or well-being. Students with high levels of activity appreciated their energy and were sure that friends loved the fun they created. Impulsiveness, on the other hand, often resulted in trouble, and those with negative impulsive behaviour expressed regret and wanted to avoid it. The qualitative empirical data showed no differences in inattentiveness, hyperactivity or impulsiveness between students with ADHD diagnoses and those without.

The present study will highlight how concentration problems affect schoolwork. The term 'concentration' is discussed in the scientific literature (Hvidsten \& Valle, 2021). However, we have found no agreed upon definitions on concentration or concentration problems, and prevalence numbers remain unknown, as 'concentration problem' is not a defined diagnosis. On the other hand, concentration problems or inattentiveness is a hallmark in several neurological conditions, such as reading disabilities (RD, or dyslexia) and mathematical disorders (MD, or dyscalculia) (Peterson et al., 2016). Further, inattentiveness is one of the core symptoms of ADHD, a disease with an average prevalence of $5 \%$ in childhood and adolescence (Tarver et al., 2014). Dyslexia and dyscalculia have high rates of co-occurrence (average $40 \%$ ) affecting more than $10 \%$ of children (Wilson et al., 2015). Thus, we understand that many students have challenges because of inattentiveness or concentration problems. Our participants used the term concentration problems, and therefore, we apply their term concentration in relation to analyses and findings in the study and attention and inattentiveness in connection with previous publications on ADHD, dyslexia and dyscalculia. We consider it outside the scope of this article to elaborate on the differences between concentration and attention.

Teachers are generally important to students (Havik \& Westergård, 2020). With regard to ADHD specifically, teachers may be even more crucial to most students. To support students with ADHD and low levels of agency, Wiener and Daniels (2015) suggested that teachers monitor and scaffold learning. In Norway, municipalities and counties are obliged to provide special education with adapted help at local schools to students who need it, and many of our students had this right. In special education content, tempo and learning context are considered. The right to obtain extra help at one's local school has been anchored in the Education Act (The Education Act, 1998) since 1975. Although the quality and consequences of special education have been critically debated in recent years (Nordahl et al., 2018), we do not discuss special education per se in this article.

The association of attention with academic achievement is widely studied (Gray et al., 2017; Polderman et al., 2010), but we have less knowledge on the students' feelings and perceptions related to experiencing concentration problems at school. Our purpose is therefore to put forward the students' stories. The study aims to explore how the students experience 1) concentration problems in relation to schoolwork, and 2) what strategies may ease learning. 


\section{Theoretical framework}

As the data clearly reveals what the individual students appreciate and do not appreciate regarding school subjects and the context, we found it appropriate to use the theoretical framework on subjective task values (Eccles \& Wigfield, 2020; Wigfield \& Eccles, 2020) and play theory (Sahlberg \& Doyle, 2019; Smith \& Roopnarine, 2019a; Øksnes \& Sundsdal, 2020).

After 35 years of empirical research and theory development, the expectancy-value theory by Eccles and colleagues is now labelled situated expectancy-value theory (SEVT) (Eccles \& Wigfield, 2020). Eccles and Wigfield (2020) acknowledge that the situation is influential for individual achievement. SEVT consists of a comprehensive model of achievement motivation. In this article, we apply only a part of the model, namely, subjective task values.

Of the subjective task values, intrinsic value is especially relevant for discussing our findings. Wigfield and Eccles (2020) state that "[i]ntrinsic value is the enjoyment one gains from doing the task" and that "[w]hen children intrinsically value an activity they often become deeply engaged in it and can persist at it for a long time" (p. 168). Eccles and Wigfield (2020) explain that items focusing on liking, enjoyment and interest in an activity are typically used to measure value.

Originally, attainment value includes the individual's identity-based importance to engage in various tasks or activities as well as their personal importance of engaging (Eccles \& Wigfield, 2020, p. 5). Most of the later research has measured personal importance, and the authors regret that the connection between attainment value and identity has been scarcely studied.

The two other subjective values are utility and costs. Utility value refers to the perceived usefulness of a task and how well it fits into present plans or future ones. Cost refers to the relationship between perceived cost and benefit, and it is suggested that individuals prefer tasks that provide higher benefit than cost. For our purpose, we will not go into detailed descriptions of different types of costs. However, it is important to note that each of the four subjective values is suggested to vary from highly positive to extremely low or even negative. Eccles and Wigfield (2020) regret that this range is often ignored in discussions of subjective task values. Together with SEVT, some aspects of play may clarify our findings.

Rather than pointing to different definitions of play, we will present some of its characteristics. Øksnes and Sundsdal (2019, p. 100) refer Dewey, who considered playfulness a mental attitude and suggested that playful behaviour was a manifestation of playfulness. Further, an editorial introduction in a recent handbook describes play behaviour as both enjoyable and valuable (Smith \& Roopnarine, 2019b). In the same handbook, one chapter (Beresin et al., 2019) is devoted to the views of Brian Sutton-Smith, one of the most acknowledged authors in the field. He said one needs to understand humour to understand play, and in his later life, he looked at play as a source of emotional survival (p. 383) and as one of four major characteristics of 


\section{A. Løhre, V. Vedul-Kjelsås \& O. Østerlie}

play, suggesting, "Play provides a great deal of fun, and in consequence a joy in being alive" (p. 396). In line with this, King emphasises that voluntary and self-directed play provides recreation (Øksnes \& Sundsdal, 2020, p. 126).

Contributing to the discussion on free play and teaching, Pramling and colleagues (2019) point to similarities: Both learning and play are contingent on previous learning and knowledge. The authors highlight that free play is open-ended and not deterministic; one never knows where the play takes the players. Similarly, they argue that even goal-directed teaching can be open-ended (p. 480). Engel (2019) supports this view and argues that teachers should take advantage of two main components in play, inquiry and invention, to open students' commitment to explore, build ideas and invent. More play in schools is also the vision of Sahlberg and Doyle (2019).

\section{Methods}

This research was conducted at a compulsory public school with grades 1-10 in a rural Norwegian municipality. As in most schools, several students struggled with learning because of concentration problems. To help those students, the school offered an intervention consisting of target shooting practice guided by certificated instructors. The intervention was evaluated by researchers (Østerlie et al., 2018) at the Norwegian University of Science and Technology (NTNU). The present inductive study uses baseline data generated before the start of this intervention.

\section{Context and participants}

The school has one class per grade and is the only one in the municipality that offers lower secondary. For upper secondary, adolescents must go to other municipalities. The participants were chosen to participate in the 2016/2017 target shooting practice program offered to students from grade 5 to 10 . Assisted by pedagogical-psychological services (PPT) the teachers, in dialogue with parents, selected the students. The main criterion for selection was concentration problems that teachers, the PPT and parents had observed and characterised as harmful to the student's learning. In total, 12 students aged 10 to 16 participated ( 5 girls and 7 boys). Most of the students had one or more diagnoses (seven were diagnosed with ADHD or ADD and some had other diagnoses e.g. dyslexia) and thus, they constituted a mixed group. Because there were more boys than girls, all students will be referred to as males (he) to protect anonymity.

\section{Data collection and analysis}

The researchers collaborated to develop a semi-structured interview guide consisting of bullet points covering hyperactivity, impulsiveness and concentration problems; experiences with schoolwork; perceptions of mastery and well-being as well 
as behaviour and mood in general. For the present study, questions on schoolwork and perceptions of concentration in the lessons are most relevant. The interviewer asked open-ended questions, such as "How do you feel about concentrating?" or "Are there any subjects you feel you do better than other subjects?". Such questions were often followed up asking for more information, such as "In what way?" or "Can you say something more about that ...?". Two of the researchers performed individual interviews in a quiet room in the school's administration area. All students agreed to have the interview recorded, and the interviewer reminded them they could leave the study at any time. A science assistant transcribed the interviews.

In preparing the evaluation report and the first study (Løhre, 2020; Østerlie et al., 2018), the researchers wrote comments, memos and initial codes. With this background, we knew the empirical material extremely well, and to search for a deeper understanding of students' perceptions and experiences related to concentration problems and learning, we decided to apply thematic analyses (Braun \& Clarke, 2006) in the present study.

Guided by Braun and Clarke's (2006) suggestions of steps in thematic analysis, we had already completed the first two. The researchers were familiar with the data (step 1) and had individually put memos and codes systematically throughout the text (step 2). For this study, only phrases related to how students experienced their concentration problems in relation to schoolwork counted as indicators for themes. In searching for themes (step 3), reviewing them (step 4), and defining and naming them (step 5), we discussed triangulating the findings and certainly our preunderstanding (Kvale \& Brinkmann, 2015), as teachers influenced some of the choices. Steps 3-5 were not isolated parts; we moved back and forth in our reasoning between the dataset, analyses and our personal and conceptual standpoints (see Terry et al., 2017 , p. 20). We developed themes and subthemes (Table 1) in a process described in more detail below.

Table 1. Main themes and subthemes addressing the aims of the study

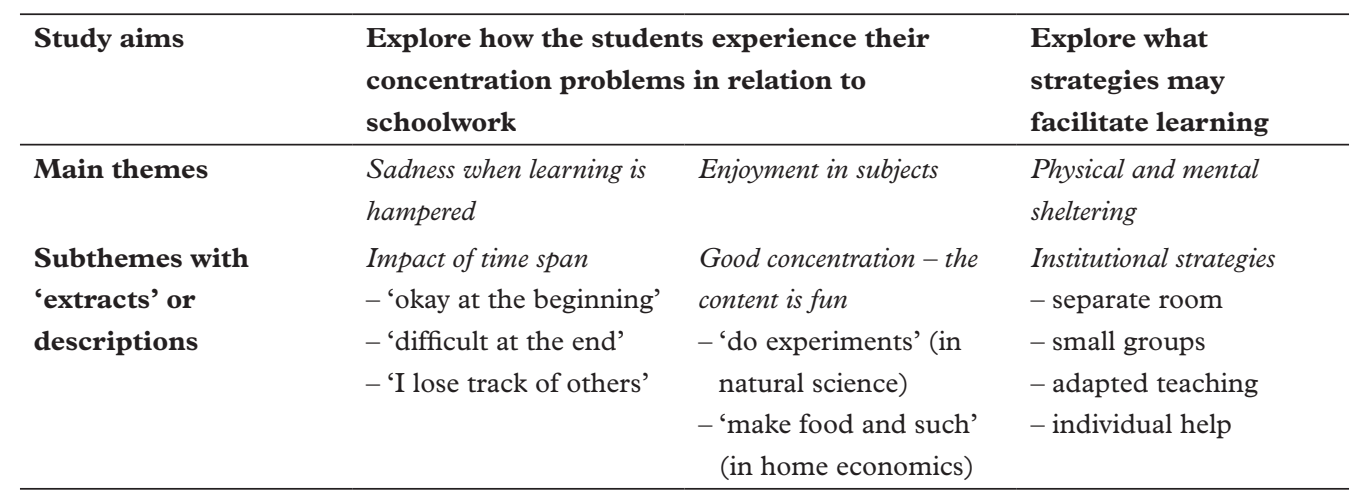


Table 1. (Continued)

\begin{tabular}{|c|c|c|c|}
\hline \multirow[t]{2}{*}{ Study aims } & \multicolumn{2}{|c|}{$\begin{array}{l}\text { Explore how the students experience their } \\
\text { concentration problems in relation to } \\
\text { schoolwork }\end{array}$} & $\begin{array}{l}\text { Explore what } \\
\text { strategies may } \\
\text { facilitate learning }\end{array}$ \\
\hline & $\begin{array}{l}\text { Traces of acceptance } \\
\text { - 'too bad, really, but } \\
\text { that's just how it is' } \\
\text { - 'grit your teeth } \\
\text { together and continue' }\end{array}$ & $\begin{array}{l}\text { Bad concentration - the } \\
\text { content is difficult, and the } \\
\text { context is exhausting } \\
\text { - 'difficult' (content) } \\
\text { - 'boring' (content) } \\
\text { - 'much noise' (context) } \\
\text { - 'much disturbance' } \\
\text { (context) } \\
\text { Individual variations - in } \\
\text { like and dislike } \\
\text { - for most subjects, the } \\
\text { like or dislike varied } \\
\text { among students; } \\
\text { a subject favoured by } \\
\text { one was disliked by } \\
\text { another } \\
\text { - Mathematics and } \\
\text { English (foreign } \\
\text { language) were disliked } \\
\text { by many } \\
\text { - Physical Education was } \\
\text { liked by the majority }\end{array}$ & $\begin{array}{l}\text { Personal strategies - to } \\
\text { make pauses or shift in } \\
\text { activities } \\
\text { - scribbling and drawing } \\
\text { at the desk } \\
\text { - leaving the desk } \\
\text { (moving and walking } \\
\text { around) }\end{array}$ \\
\hline
\end{tabular}

In our search for experiences related to schoolwork and concentration problems, we became aware of sad emotions when some students reflected on bad concentration. The interviewer never directly asked about any related feelings or emotions. Sadness emerged as an undertone in some of the stories, and we decided to label this theme Sadness when learning is hampered with subthemes Impact of time span, Experiences of loss and Traces of acceptance. Although the theme is not representative of most students, we think it is important to highlight this aspect for our sample. Further, we saw that experiences of enjoyment and fun were important for the students to keep their concentration, and labelled this theme Enjoyment in subjects with subthemes Good concentration, Bad concentration and Individual variations. The interviews provided much information on the relationship between concentration and enjoyment, and therefore, the theme and subthemes were broadly presented. We found that each student had their own story of enjoyment. Different school subjects might generate frustration and bad concentration in some students, whereas for others, the same subjects led to enjoyment. Regarding strategies to underpin learning, we found that one strategy was related to the context and initiated by the school. In step 3, we 
named this theme Importance of the environment. Additionally, the students also initiated their own strategies to get a break from exhausting tasks, which we labelled Personal strategies to regain concentration. However, in the reviewing phase (step 4), we merged the last two candidate themes into one theme, Physical and mental sheltering, with the previous candidates as subthemes: Institutional strategies and Personal strategies. To ensure necessary relationships between coded data, themes and aims (Terry et al., 2017), we checked Table 1. Telling the story in the empirical part (step 5) led us to develop Figure 1 to visualise the relationships between data and theories of play and motivation. The theories functioned as co-requisites (Terry et al., 2017, p. 20) in the analysis. In completing the article (step 6), we further developed the figure to also include and depict the latent content related to the SEVT theory (right side of Figure 2). The students' identities are marked alphabetically from SA to SL.

\section{Ethics}

The researchers explained the evaluation in information letters as well as in meetings with parents and teachers. Such information addressed the option to withdraw from the evaluation study at any time without explanations. Students, parents and other informants signed written informed consent forms. The Norwegian Centre for Research Data approved the research.

\section{Students' stories}

Themes about sadness and enjoyment explore the first part of the study's aim looking at concentration problems in relation to schoolwork. The last theme investigate strategies to underpin learning.

\section{Sadness when learning is hampered}

All 12 students had concentration problems that obstructed their learning as reported in the introduction. However, some of them seemed to reflect more on this than others, and for those who shared their thoughts and emotions with the interviewer, sadness emerged as an undertone. They could not follow the pace of their peers. Even if they tried hard, their concentration weakened throughout the lesson:

I can feel that it's okay at the beginning of the lesson, and as the lesson proceeds, I can hardly write and then I just wait a bit with writing, but then I lose track of what the others are doing. SD

For example, at the end of the lesson when I am a bit bored, then it is difficult to concentrate. SK

The next two statements additionally express an experience of loss. Compared with peers in class, the students realised that they were learning less. Without saying it directly, they might think about the future in utterances regarding losing knowledge and apprenticeship: 


\section{A. Løhre, V. Vedul-Kjelsås \& O. Østerlie}

That I will not learn as much as the others. That I lose my apprenticeship, sort of. SA

There are many things that I don't understand and that I don't master properly. Losing a bit of the knowledge. It is too bad, really, but that's just how it is, I guess. SG

For some students, the days varied a lot because of sleeping problems. After nights of bad sleep, their concentration was negatively affected, and they could not keep track during the school day. This led to gaps in knowledge, and subsequently to sad feelings, as was the case for student $\mathrm{G}$ above. At the same time, his quote, as well as the last one, also includes some acceptance of the situation:

I know that I'm struggling a bit and stuff. Then I know, that's just how it is. Then it is just to grit your teeth together and continue. SC

The emotions and utterances that cover sadness were in the lower range of intrinsic value (see Figure 1). The students felt they struggled and that their learning was hampered because of bad concentration. We did not see signs of playfulness or enjoyment in these stories.
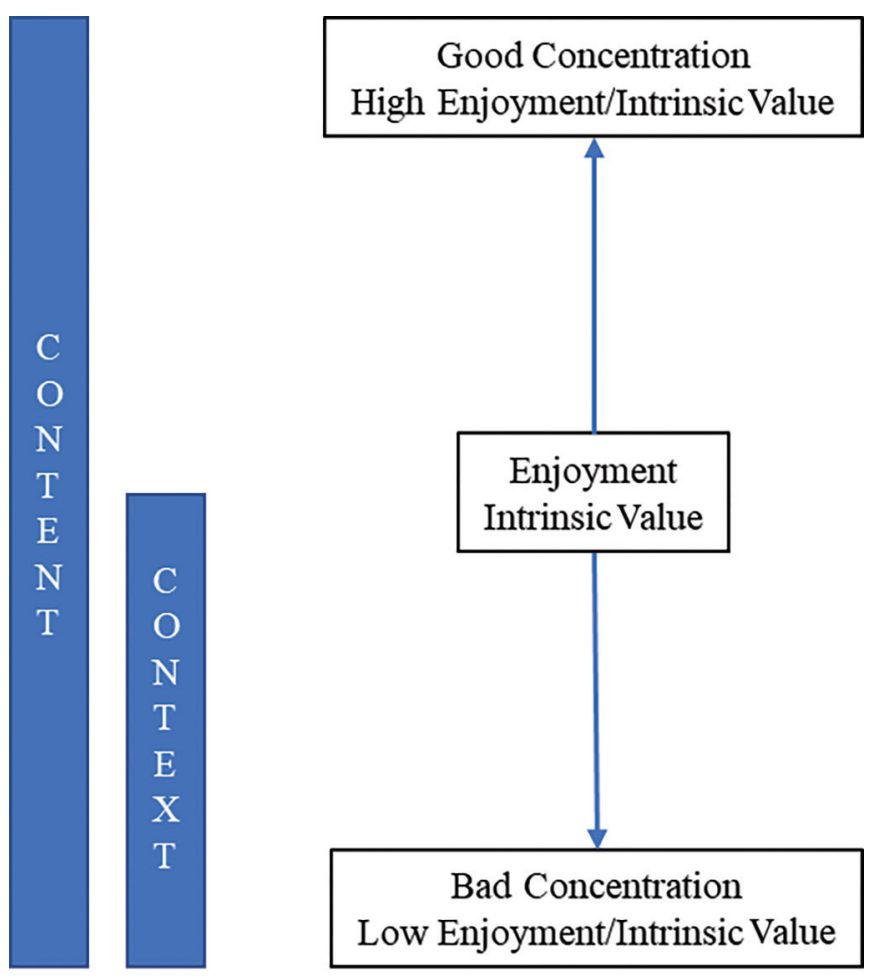

Figure 1. The importance of content and context in relation to concentration and enjoyment (C) Løhre, Vedul-Kjelsås \& Østerlie. 


\section{Enjoyment in subjects}

In this section, the students' perceptions of concentration are seen together with experiencing fun. Additionally, the importance of the content and the context is presented, as reflected by the students. The theme also shows substantial individual variations in the students' like or dislike of subjects.

My concentration is best when we have subjects that I find interesting. SJ

Like student $\mathrm{J}$, many of the informants said that their concentration was better when they liked the subject and found it enjoyable or interesting. Different students mentioned various subjects in which they were able to concentrate better compared with other subjects, but there was one common factor in their statements: The students perceived to have better concentration when they enjoyed the subject. They had to like the content of the subject to put effort into the tasks:

And natural science, it's a lot of fun because then we are down in the natural science room and do experiments. It's easy to concentrate then because we do something sort of fun. SE

Home economics. We started with that subject in ninth grade. I think it is fun... because you make food and such. SI

It is easiest to concentrate in social science... I think it is a fun subject. SD

These quotes show that the students often used the word 'fun' when they liked the subject and the content, and their enjoyment was related to good concentration. Opposite to this, we found the words 'difficult' or 'boring' when they disliked the content, and the students typically linked this to perceptions of bad concentration. We let a couple of quotes illustrate this negative aspect:

The subjects that are boring. Become unfocused and bored in the subjects that are obligatory. SG

A little difficult in difficult subjects. It goes well in maths. SA

Also, the context might give rise to bad concentration. For some students, more than for others, noise and movements in the room were exhausting. This seemed especially true in subjects perceived as unstructured, such as Art and Crafts and Home Economics:

In Art and Crafts, we sit [in groups] four and four and sometimes five. So, then there is more talking. And much noise [...] and I have to remember this and that, and maybe I forget one thing and then I will have to go one more trip. And then I see something on the way and then I stop to say how nice it looked and then I sometimes forget to sit back down again. SB

Because there is so much disturbance [in Home Economics]. Because you have to go back and forth and back and forth to fetch the things and then some will have to stand in line. SA 


\section{A. Løhre, V. Vedul-Kjelsås \& O. Østerlie}

Further, it is important to note individual variations in liking or disliking a specific subject. One subject that provided enjoyment for some students might frustrate others. The above accounts exemplify this. Student A complained about disturbances in Home Economics while student I said he found this subject fun and linked his pleasure to the content and to what they do: "you make food and such". Corresponding contradictions were obvious in most subjects.

Mathematics and foreign language (English) were the two subjects that resulted in the most disengagement. Only three of the twelve students said they liked math, and student A was one of them. He was also the only one who experienced mastery in the subject. According to this student, he considered structure and rules to be the main reasons for his preference and mastery: "There is more structure and there are rules for how to make calculations" (SA). In total, seven students clearly expressed that they disliked Mathematics. From the reports below, we see that dislike is related to content; arithmetic is difficult to cope with:

Mathematics, I don't like maths because it is very difficult ... for instance some multiplication and division tasks. But I know how to do it. SE

It is just full of things [in Mathematics]. Which are written down, and which I don't understand. $\mathrm{SH}$

Like and dislike for English were roughly the same as for Mathematics. One student said he liked English and six disliked it. Of those who disliked the subject, two students told the interviewer it was because they had dyslexia. Few students said anything about the subject Norwegian language, but the student below links problems in English with problems in Norwegian:

It will have to be English. I struggle with writing in Norwegian and then it becomes twice as difficult in English. SC

Contrary to the subjects that many students disliked, there was one favourite subject that stood out. Eight of the twelve students spontaneously claimed that they loved Physical Education. Explaining why they liked this subject, they all argued that the reason was physical activity:

I like to be active. SK

It is activity and we get to be outside. SI

Because then I can move around and such things. SH

This theme has shown that the students' experiences and perceptions associated with the content in the subjects cover the whole range of intrinsic motivation (Figure 1), and playfulness and fun seem to be integrated into engagement. When concentration 
and intrinsic motivation were at their highest, they seemed to produce a playful and happy engagement. At the other end of the range, where concentration and intrinsic motivation were low, we found no signs of playfulness, joy or fun. Regarding this theme, it is of utmost importance to note some characteristics in the students' preferences. What characterises these preferences most is diversity. The only pattern is that most of the students liked Physical Education whereas about half disliked English or Mathematics.

\section{Physical and mental sheltering}

First, this section describes the students' perceptions and feelings related to receiving adapted teaching outside the classroom. Second, we present what the students did to shelter themselves in the classroom.

Those who discussed having lessons in a small group room appreciated this context in contrast with being in the classroom. The group room provided fewer disturbances because it had only a few students. Further, the teacher could help each of them individually according to the extra help and adaptation they needed. The importance of sheltering to concentrate and feel calm is expressed by student I below, as well as in the dialogue between student $\mathrm{A}$ and the interviewer:

It is no problem if I sit by myself or together with only a few others. But if I sit in the classroom and there are many students talking I kind of become more interested in what they are doing. We have an extra teacher in the subjects where we need extra help. Such as in maths, me and three or four others are taken out to a separate room and [we] go through the material again. SI

SA: Yes, at least when I work with only teacher, that works better.

I: Works better than?

SA: When I'm in the classroom.

I: Can you say something about how it's different?

SA: I become calmer when I'm with the teachers. It feels really good. Because then I am calmer, and it is explained more clearly. And when I'm in the classroom there's more fuss.

I: There's more fuss? How?

SA: There's more talking then.

Being in the group room provided both mental and physical sheltering. This educational practice was arranged by the school. In addition, some students used their own strategies to mentally avoid disturbances in the classroom. The interviewer did not systematically ask if those strategies were agreed upon by teachers, but the teachers clearly accepted that some students took mental or physical pauses from their work in class.

When the students felt exhausted and unable to concentrate, they started to do something else. This shift in activity can mainly be sorted into two groups: either they left their desk or they turned to daydreaming in quiet scribbling or drawing. 


\section{A. Løhre, V. Vedul-Kjelsås \& O. Østerlie}

Several of the students used drawing as a strategy for mental pauses. For example, the interviewer talked with student $\mathrm{L}$ about his difficulties concentrating over time, and he answered, "I cannot sit too long, then my concentration disappears, it does. Then I need to take pauses and such". Further, student L said he needed a pause after 10 minutes if the task was difficult, but he could manage more than half an hour if it was something easy. Below, two dialogues illustrate the students' autonomy in using pauses as a strategy:

I: How is your behaviour in the classroom when you work with difficult things and it's hard to concentrate?

SD: I must sit there, you know. Do some small drawings in my book.

I: Is it easier to do something else? Draw in the book, or?

SD: Oh, yeah, I need to have a little pause now and then.

In the next dialogue, the interviewer asked if concentration was worse after a night of little sleep and what happens if he gets a message in the classroom, and the student answered as follows:

SB: I try to remember it, but I do not always remember it.

I: What happens if you afterwards get a task of writing something?

SB: Then I take a few minutes off.

I: Okay, what do you do in those minutes?

SB: Draw a little. When I draw, I become quiet. My thoughts sort of disappear.

I: Okay. Has someone helped you or told you to do so?

SB: No, it's something I have found out for myself.

I: Yes. So, your teacher know that you do it?

SB: Sometimes.

The dialogue continued with the student saying that he has talked with his parents about taking pauses to draw, and he said he used the same strategy at home; if he is tired and loses concentration, he draws a little, and then he is ready to do some homework again. Other students could not remain seated quietly by their desks, and therefore they leave their place. The dialogue below illustrates how some students apparently regulated their breaks by a shift leading to physical activity:

I: Do you feel it's difficult, for instance during a class at school, that it's difficult to sit still?

SG: Yes, I do. I feel that I must get up and walk around and move about. Feel that I have a need to get up and move about.

This theme is mainly linked to the lower range of Figure 1, where both the context and content are essential to learn. The personal strategies of scribbling and drawing signalise ease and playfulness in self-chosen situations. Further, institutional strategies helped the students to feel well and calm in the sheltered context. Such emotions are in contrast with the sadness in the first theme. 


\section{The significance of the students' information}

From the students' stories, we found enjoyment a core experience in their valuation of schoolwork. High enjoyment was related to good concentration and playfulness, whereas low enjoyment was associated with low concentration and perceived academic difficulties, giving some students feelings of frustration and sadness. The likes and dislikes of specific subjects reflected diversity. Students who liked one subject and disliked others were contrasted by peers with quite opposite preferences. For students who struggled in some subjects, the school provided adapted teaching individually or in groups in another room. Such sheltering made it easier to concentrate and learn. Everyone who had this option said they felt calm and well in the sheltered context. Also, when the classroom atmosphere became exhausting to some students, they created their own mental or physical pauses.

\section{Enjoyment as a driving force}

Enjoyment was of utmost importance to the students, and they clearly related enjoyment to concentration. The students frequently used the word 'fun' in connection with liking a subject. This corresponds to intrinsic value in SEVT (Eccles \& Wigfield, 2020) in which fun, liking and enjoyment are typical labels, and we find the same characteristics in play theory (Sahlberg \& Doyle, 2019; Smith \& Roopnarine, 2019a). We see that the students' evaluations cover the whole range of one subjective task value - intrinsic value - from extremely high to negative. This adds to the empirical base of SEVT as called for by Eccles and Wigfield (2020).

We interpreted feelings of loss and being academically left behind by peers in class as sad emotions, and those feelings were related to the negative end of intrinsic value. At the same time, those feelings may correspond to the aspect of identity in attainment value, as a low degree of perceived success in a subject might influence self-confidence and identity in that specific area. Thus, the finding helps reduce the gap in one's knowledge of identity in attainment value, which Eccles and Wigfield (2020) find unfortunate. We add a new quote to illustrate the possible relationships between values in SEVT:

It's got to do with how I view things. If I think it sounds really boring and know that it is very boring, then I don't feel like doing it, either... Sometimes I can think that it will be difficult and then I don't manage to do it very well... but it depends on how much I want to practice. On how much I want to do well. SI

This student reveals mature reflections, saying it has to do with how he views things. The words 'really boring' and 'difficult' show this topic is at the negative end of intrinsic value. Further, expected success was related to the effort he decided to put into task (costs) and to evaluation of importance (attainment value). In the empirical part of the article, we suggested that loss and sadness might involve thoughts on later education and life. If this is the case, the utterances may also relate to the value usefulness. Possible relationships between values are presented on the right side of Figure 2. 

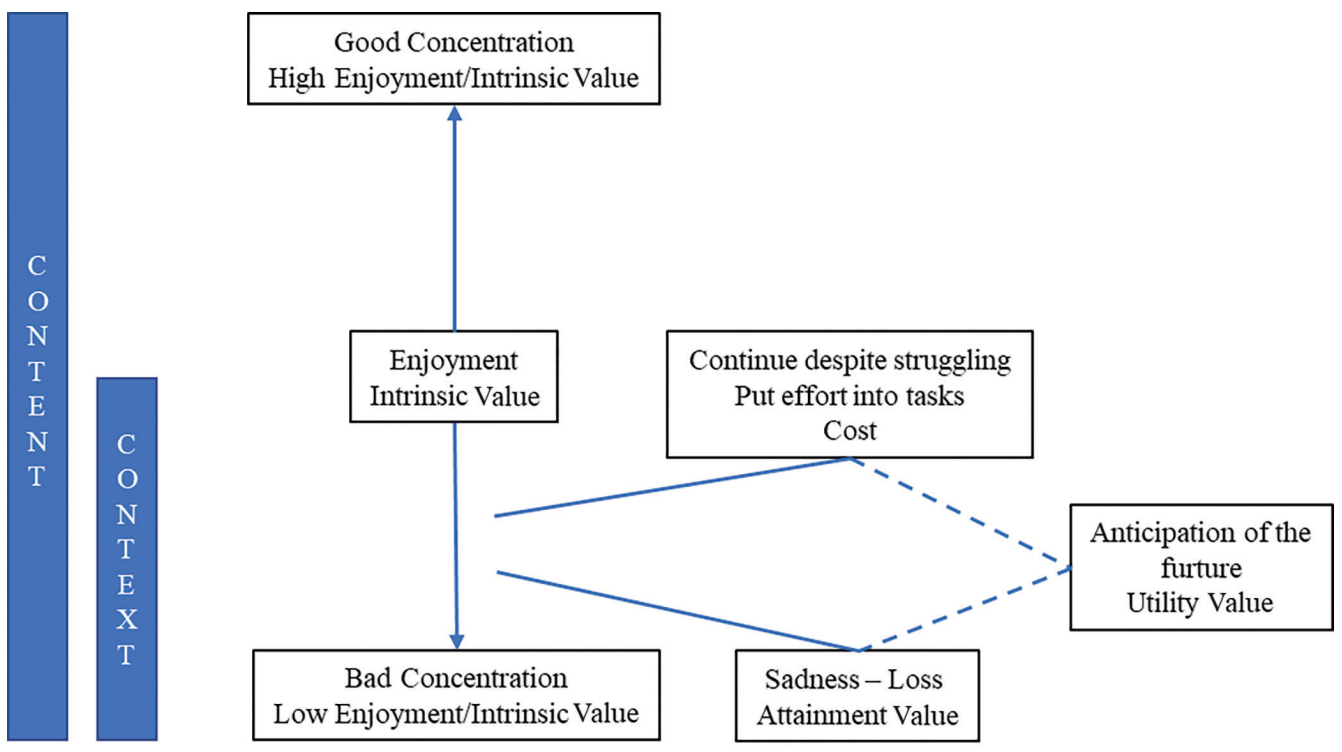

Figure 2. Relationships between subjective task values, concentration and enjoyment, reflected by the importance of content and context $(C$ Løhre, Vedul-Kjelsås \& Østerlie.

The analyses demonstrated that attainment value, cost and possibly usefulness were concentrated in relation to the lower part of intrinsic value. We wonder why these values were not associated with the upper part. According to the literature on play (Engel, 2019; Sahlberg \& Doyle, 2019), enjoyment in play fosters creativity and positive development. Our students admittedly expressed pleasure and joy when they talked about subjects they liked, but this seemed to be detached from perceptions of identity and importance and thus detached from attainment value. In a previous publication (Løhre, 2020), we discussed that being funny and creating fun together with friends seemed to positively influence identity in students with high levels of activity. Now we wonder whether feelings of proudness were linked solely to behaviour in interaction with peers and not to schoolwork and subjects. Perhaps the students were less acquainted with compliments on their happiness at the upper end of intrinsic value. Another explanation of the relationships depicted in Figure 2 can be attributed to the interview situation. The students were asked to discuss subjects they liked and subjects they did not like, if any. The interviewer followed up by asking why the student liked or disliked a subject, but there was no elaboration into the student's perceptions or emotions related to high degrees of success. One advice for later studies is to explore levels of enjoyment more deeply in relation to attainment values in students with concentration problems.

\section{Institutional and personal strategies to increase concentration}

In a learning situation, both the content of the task/subject and the context of the learning situation are important to outcomes. The analyses showed that content was 
linked to the whole scale of intrinsic value from high to low enjoyment. At the positive end with high enjoyment, everything was fine. Here, the students' reports provided associations with play, where corresponding descriptions of joy and fun are central; see, for example, Sutton-Smith (in Beresin et al., 2019). Further, we must note that the students did not mention the context as central when they talked about high levels of enjoyment and concentration in subjects. At the opposite end with low intrinsic value, the context was crucial when the students experienced difficulties and bad concentration.

For students who struggled in basic subjects and experienced disturbances as sources of bad concentration, the school offered adapted teaching in a silent room. All students who mentioned this learning context appreciated the possibility of leaving the classroom. They felt learning was easier in a sheltered context. The students also underlined the importance of individually adapted content and that they obtained more individual help through these institutional strategies.

The main intention of personal strategies was clearly to regain concentration. To avoid all impressions in the classroom, some of the students chose to mentally or physically escape for a while. Many resorted to drawing or scribbling in books while others stood up and moved around. Contrary to institutional strategies, personal strategies did not directly involve learning. Indeed, some students might unconsciously scribble in their books or stand up. However, several of our participants did this shift in activities to join educational work afterwards. This corresponds to King's emphasis on play as recreation (in Øksnes \& Sundsdal, 2020) and Sutton-Smith's source of survival (Beresin et al., 2019). We are not aware of publications that explore or discuss autonomy in administrating pauses among students with harmful concentration problems. It could be a fruitful path to further investigate conscious choices and autonomy in shifts of activity and likewise explore who benefits the most by being allowed to administrate their own pauses.

\section{The interplay between enjoyment, concentration and success}

The relationships depicted in Figure 2 send an important message to educators: Enjoyment is central for students to succeed in their learning. Existing knowledge has already found a strong connection between concentration and academic success (Peterson et al., 2016), but the interplay with enjoyment is less elaborated for students with concentration problems. The value of joy might have been overlooked in the students' learning. In general, the literature suggests that play nurtures students (Sahlberg \& Doyle, 2019; Smith \& Roopnarine, 2019a), and perhaps aspects of play, like enjoyment, physical activity and creativity, are especially important for students with concentration problems. This interplay between concentration, enjoyment, motivation and success in learning should be broadly studied for students with $\mathrm{ADHD}$ and others who struggle with learning in language subjects and Mathematics.

Teachers face great challenges in organising individual students' preferences and engagement (Havik \& Westergård, 2020). According to the diversity of preferences in 


\section{A. Løhre, V. Vedul-Kjelsås \& O. Østerlie}

our findings, students with concentration problems cannot be treated as a group. In correspondence with researchers advocating for agency (Wiener \& Daniels, 2015), one teaching strategy might be to support the student's agency in terms of letting them choose their own pauses and further determine whether the classroom or a sheltered area is the best context for learning depending on the topic and fitness of the student. Another strategy could be to integrate elements of play in the work of learning, such as inquiry and invention (Engel, 2019) and open-ended learning (Pramling et al., 2019) to nurture an attitude of playfulness (cf. Dewey in Øksnes \& Sundsdal, 2020). For students with concentration problems as well as for others, more elements of play could preferably be included in teaching from the early years of education.

\section{Limitations}

The students' own stories are strengths in this study, which brings new knowledge on the interplay between concentration, motivation and play. In the analysis, we followed Braun and Clarke (2006) and Terry et al. (2017) by interpreting both manifest and latent content in a nonlinear process where we alternately focused on data and theory. However, our preunderstanding as teachers (Kvale \& Brinkmann, 2015) has clearly influenced the empirical presentation and discussion. The essential role of enjoyment needs to be investigated in other datasets on students with concentration problems. Also, the theoretical link between motivation and play only touches the surface in the present article, and critical work on this in relation to learning and adapted teaching for the target group is welcomed. As a basis for comparison, we hope that our detailed descriptions of methods and findings are helpful.

\section{Conclusion}

The students' stories inspired us to investigate the relationships between 'motivation', 'play' and what students and teacher refer to as 'concentration'. As there is substantial scientific knowledge on attention (concentration), play and motivation as separate concepts, but less on the interaction between these factors, the study brings new knowledge to the field. The students typically valued a task or a subject according to perceptions of enjoyment, and high or low enjoyment was systematically linked to high or low concentration. The students' diversity in preferences can be a challenge to teachers. However, in subjects where the students struggle, they highlighted the importance of a sheltered learning context with adapted teaching. We argue that elements of play can be included in topics that are perceived as difficult.

\section{Author biography}

Audhild Løhre, Associate Professor, Section of Pedagogy, Department of Teacher Education, NTNU. Løhre has special research interests in promotion of students' learning, well-being and health in educational settings. 
Vigdis Vedul-Kjelsås, Associate Professor, Section for Art, Physical Education and Sports, Department of Teacher Education, NTNU. Central research interests are motor competence, self-perception, diversity and inclusion in physical education.

Ove Osterlie, Associate Professor, Section for Art, Physical Education and Sports, Department of Teacher Education, NTNU. Østerlie's research is focused on the implementation of digital tools in physical education, and research on students with concentration difficulties.

\section{References}

Beresin, A., Brown, F., \& Patte, M. M. (2019). Brian Sutton-Smith's views on play. In P. K. Smith \& J. L. Roopnarine (Eds.), The Cambridge handbook on play: Developmental and disciplinary perspectives. Cambridge University Press.

Braun, V., \& Clarke, V. (2006). Using thematic analysis in psychology. Qualitative Research in Psychology, 3(2), 77-101. https://doi.org/10.1191/1478088706qp063oa

Eccles, J. S., \& Wigfield, A. (2020). From expectancy-value theory to situated expectancy-value theory: A developmental, social cognitive, and sociocultural perspective on motivation. Contemporary Educational Psychology, 61. https://doi.org/10.1016/j.cedpsych.2020.101859

The Education Act. (1998). Act relating to primary and secondary education and training (LOV-1998-07-17-61). https://lovdata.no/dokument/NLE/lov/1998-07-17-61

Engel, S. (2019). The problems of play. In P. K. Smith \& J. L. Roopnarine (Eds.), The Cambridge handbook of play: Developmental and disciplinary perspectives. Cambridge Publisher Press.

Gray, S. A., Dueck, K., Rogers, M., \& Tannock, R. (2017). Qualitative review synthesis: The relationship between inattention and academic achievement. Educational Research, 59(1), 17-35. https://doi.org/10.10 $80 / 00131881.2016 .1274235$

Havik, T., \& Westergård, E. (2020). Do teachers matter? Students' perceptions of classroom interactions and student engagement. Scandinavian fournal of Educational Research, 64(4), 488-507. https://doi.org/10.10 $80 / 00313831.2019 .1577754$

Hvidsten, B. B., \& Valle, A. M. (2021). Counsellors perceptions of the phenomenon of concentration difficulties. Support for Learning, 36(1), 83-101. https://doi.org/10.1111/1467-9604.12340

Kvale, S., \& Brinkmann, S. (2015). Interviews: Learning the craft of qualitative research interviewing (3rd ed.). SAGE Publications.

Løhre, A. (2020). Identity formation in adolescents with concentration problems, high levels of activity of impulsiveness: A pragmatic qualitative study. International fournal of Educational Psychology, 9(1), 1-23. http://dx.doi.org/10.17583/ijep.2020.4315

Nordahl, T., Persson, B., Dyssegaard, C. B., Hennestad, B. W., Wang, M. V., Martinsen, J., Vold, E. K., Pia Paulsrud, P., \& Johnsen, T. (2018). Inkluderende felleskap for barn og unge [Inclusive community for children and young people]. Fagbokforlaget. https://nettsteder.regjeringen.no/inkludering-barn-unge/files/2018/04/ INKLUDERENDE-FELLESSKAP-FOR-BARN-OG-UNGE-til-publisering-04.04.18.pdf

Peterson, R. L., Boada, R., McGrath, L. M., Willcutt, E. G., Olson, R. K., \& Pennington, B. F. (2016). Cognitive prediction of reading, math, and attention: Shared and unique influences. Fournal of Learning Disabilities, 50(4), 408-421. https://doi.org/10.1177/0022219415618500

Polderman, T. J. C., Boomsma, D. I., Bartels, M., Verhulst, F. C., \& Huizink, A. C. (2010). A systematic review of prospective studies on attention problems and academic achievement. Acta Psychiatrica Scandinavica, 122(4), 271-284. https://doi.org/10.1111/j.1600-0447.2010.01568.x

Pramling, N., Kultti, A., \& Samuelsson, I. P. (2019). Play, learning, and teaching in early childhood education. In P. K. Smith \& J. L. Roopnarine (Eds.), The Cambridge handbook of play: Developmental and disciplinary perspectives. Cambridge University Press.

Sahlberg, P., \& Doyle, W. (2019). Let the children play. Oxford University Press. 


\section{A. Løhre,V. Vedul-Kjelsås E̊ O. Østerlie}

Smith, P. K., \& Roopnarine, J. L. (Eds.). (2019a). The Cambridge handbook of play: Developmental and disciplinary perspectives. Cambridge University Press.

Smith, P. K., \& Roopnarine, J. L. (2019b). Editorial introduction. In P. K. Smith \& J. L. Roopnarine (Eds.), The Cambridge handbook of play: Developmental and disciplinary perspectives. Cambridge University Press.

Tarver, J., Daley, D., \& Sayal, K. (2014). Attention-deficit hyperactivity disorder (ADHD): An updated review of the essential facts. Child: Care, Health and Development, 40(6), 762-774. https://doi.org/10.1111/cch.12139

Terry, G., Hayfield, N., Clarke, V., \& Braun, V. (2017). Thematic analysis. In C. Willig \& W. S. Rogers (Eds.), The SAGE handbook of qualitative research in psychology. SAGE Publications Ltd.

Wiener, J., \& Daniels, L. (2015). School experiences of adolescents with attention-deficit/hyperactivity disorder. Fournal of Learning Disabilities, 49(6), 567-581. https://doi.org/10.1177/0022219415576973

Wigfield, A., \& Eccles, J. S. (2020). 35 years of research on students' subjective task values and motivation: A look back and a look forward. In A. J. Elliot (Ed.), Advances in motivation science. Academic Press.

Wilson, A. J., Andrewes, S. G., Struthers, H., Rowe, V. M., Bogdanovic, R., \& Waldie, K. E. (2015). Dyscalculia and dyslexia in adults: Cognitive bases of comorbidity. Learning and Individual Differences, 37, 118-132. https://doi.org/10.1016/j.lindif.2014.11.017

Øksnes, M., \& Sundsdal, E. (2020). Barns lek $i$ skolen. Fagbokforlaget.

Østerlie, O., Buaas, I. Ø., Vedul-Kjelsås, V., \& Løhre, A. (2018). Skytetrening for elever med konsentrasjonsvansker: Evaluering av et tiltak $i$ skolen (NTNU Oppdragsrapport 2018). NTNU Open. http://hdl.handle. net/11250/2478346 